\title{
Aa. Vv., Erotica Vetera, Hommage à Rose M. Bidler
}

\section{Maria Colombo Timelli}

\section{(2) OpenEdition}

\section{Journals}

Édition électronique

URL : https://journals.openedition.org/studifrancesi/39002

DOI : 10.4000/studifrancesi.39002

ISSN : 2427-5856

Éditeur

Rosenberg \& Sellier

\section{Édition imprimée}

Date de publication : 1 décembre 2004

Pagination : 339

ISSN : 0039-2944

\section{Référence électronique}

Maria Colombo Timelli, «Aa. Vv., Erotica Vetera, Hommage à Rose M. Bidler », Studi Francesi [En ligne], 143 (XLVIII | II) | 2004, mis en ligne le 30 novembre 2015, consulté le 19 mai 2021. URL : http:// journals.openedition.org/studifrancesi/39002 ; DOI : https://doi.org/10.4000/studifrancesi.39002

Ce document a été généré automatiquement le 19 mai 2021.

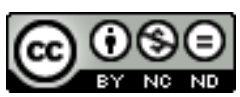

Studi Francesi è distribuita con Licenza Creative Commons Attribuzione - Non commerciale - Non opere derivate 4.0 Internazionale. 


\title{
Aa. Vv., Erotica Vetera, Hommage à Rose M. Bidler
}

\author{
Maria Colombo Timelli
}

\section{RÉFÉRENCE}

«Le moyen français», 50, 2002. Erotica Vetera, Hommage à Rose M. Bidler. le «Petit Jehan de Saintré» et dans la nouvelle XCIX des «Cent Nouvelles Nouvelles» pp. 13-29) décèle dans deux récits d'Antoine de La Sale une véritable didactique et clinique de l'amour, fondée peut-être sur le traité d'Arnoud de Villeneuve (XIII ${ }^{e}$ siecle). Dans la seconde partie du Saintré, la boulimie s'affirme comme remède à la maladie d'amour qui a frappé la Dame des Belles Cousines: le langage de l'érotisme reste aussi discret et allusif que dans la première partie du roman, alors que la description de la débauché alimentaire prend décidément le dessus. Dans la nouvelle, en revanche, c'est l'abstinence, aussi bien alimentaire que charnelle, qui est proposée comme traitement de la concupiscence. En condusion, selon les mots de C.G., chez La Sale «le langage érotique est fait surtout de silences et de blancs» (p. 29). pp. 61-69) compare deux châteaux de la littérature du XVe siècle: le châteaux de Plaisance dans Le Cuer d'Amours espris de René d'Anjou (1457) et le châteaux pris d'assaut au début du Champion des Dames de Martin Le Franc (vers 1440). Ces deux bâtiments s'opposent radicalement: l'un est aussi brillant que vide, aussi éclatant que creux, alors que l'autre, dont les murs sont faits de diamant, est le symbole univoque d'un amour solide, pur et rayonnant.

GIOVANNA ANGELI, Encore sur Boccace et Christine de Pizan: remarques sur le «De mulieribus claris» et le «Livre de la Cité des Dames" («Plourer, parler, filer mist Dieu en femme» I, 10), pp. 115-125. 
5 A partir de la triade qui ouvre la Cité des Dames, véritable «vocabulaire des actions féminines», G.A. mène une fine comparaison entre les deux textes de Boccace et de Christine, avec de nombreux exemples à l'appui. Elle constate ainsi que chez Boccace les femmes illustres abdiquent de fait à la pratique et aux métiers féminins, alors que chez Christine le problème peut paraître esquivé, mais en réalité les femmes ne sont jamais obligées d'exhiber une virilité qu'elles auraient éventuellement acquise. 